\title{
White Oak Pollen IgE Antibody Measurement
}

National Cancer Institute

\section{Source}

National Cancer Institute. White Oak Pollen IgE Antibody Measurement. NCI Thesaurus. Code C147282.

The determination of the amount of white oak pollen IgE antibody present in a sample. 